


\section{DISCLAIMER}

This report was prepared as an account of work sponsored by an agency of the United States Government. Neither the United States Government nor any agency Thereof, nor any of their employees, makes any warranty, express or implied, or assumes any legal liability or responsibility for the accuracy, completeness, or usefulness of any information, apparatus, product, or process disclosed, or represents that its use would not infringe privately owned rights. Reference herein to any specific commercial product, process, or service by trade name, trademark, manufacturer, or otherwise does not necessarily constitute or imply its endorsement, recommendation, or favoring by the United States Government or any agency thereof. The views and opinions of authors expressed herein do not necessarily state or reflect those of the United States Government or any agency thereof. 


\section{DISCLAIMER}

Portions of this document may be illegible in electronic image products. Images are produced from the best available original document. 


\section{LEGAL NOTICE}

This report was prepared as an account of Government sponsored work. Neither the United States, nor the Commission, nor any person acting on behalf of the Commission:

A. Makes any warranty or representation, expressed or implied, with respect to the accuracy, completeness, or usefulness of the information contained in this report, or that the use of any information, apparatus, method, or process disclosed in this report may not infringe privately owned rights; or

B. Assumes any liabilities with respect to the use of, or for damages resulting from the use of any information, apparatus, method, or process disclosed in this report.

As used in the above, "person acting on behalf of the Commission" includes any employee or contractor of the Commission, or employee of such contractor, to the extent that such employee or confractor of the Commission, or employee of such contractor prepares, disseminates, or provides access to, any information pursuant to his employment or contract with the Commission, or his employment with such contractor.

\section{PACIFIC NORTHWEST LABORATORY \\ RICHLAND, WASHINGTON \\ operated by}

BATTELLE MEMORIAL INSTITUTE

for the

UNITED STATES ATOMIC ENERGY COMMISSION UNDER CONTRACT AT(45-1)-1830 


\title{
INTERNAL DEPOSITIONS OF RADIONUCLIDES IN MAN
}

\begin{abstract}
These studies are concerned with the continued development and improvement of diagnostic techniques for the assessment of internal depositions of radiotoxic materials in man. The studies are restricted primarily to investigation of radionuclides of interest to the nuclear industry which are difficult or impossible to reliably assess in vivo through the use of external radiation detectors such as whole body counters. Because of this restriction, analysis of body excretion is the usual method of diagnosis, quantification of which is accomplished through excretion studies on human test subjects. Since the radionuclides of interest are usually highly radiotoxic, substitute isotopes which have good measurement sensitivity but which are much less radiotoxic are developed for use in human testing studies. Animal studies performed to give basis for human studies also permit correlation of metabolic parameters between man and animats which in turn can give basis to other animal studies.
\end{abstract}

Plutonium

I. C. Nelson and D. McConnon

Our current interest in plutonium is the development of a diagnostic method to be used in the presence of chelating agents used for therapeutic removal of plutonium. In addition, human testing performed for the above would add basis to the early work of Langham, et al. The process of preparing test quantities of ${ }^{237} \mathrm{Pu}$, the substitute isotope for several highly toxic plutonium isotopes, involves cyclotron irradiation and, as it turns out, has involved long turn-around times. Two full irradiation sequences were completed this year. The first was an irradiation of $99+\%$ enriched ${ }^{235} \mathrm{U}_{3} \mathrm{O}_{8}$ which resulted in a yield one tenth that of the previously used $93 \%$ enriched uranium-235 metal foil experiments but the product was still con-

taminated with an excessive amount of the long-lived alpha-emitting radionuclides ${ }^{236} \mathrm{Pu}$ and $238 \mathrm{Pu}$. This poorer yield was attributed to non uniformity of irradiation and it was decided to discontinue use of $\mathrm{U}_{3} \mathrm{O}_{8}$ targets in favor of the more easily prepared metal foil targets. The second experiment consisted of three separate foils irradiated for shorter times at three different energies. This test will provide information relative to the trade 
otf of 237 ru yield in favor of re duced amounts of contaminating $236 \mathrm{pu}$ and $238 \mathrm{Pu}$ Separation within $24 \mathrm{hr}$ after irradiation was also performed to reduce the ingrowth of these plutonium contaminants from neptu nium decay. Analyais of these samples is still in progress

A plutonium tiscue monitor was designed and prototype built which was tested in the morgue of the local hospital Fabrication of the per manent device is in progress This device is for use by the pathologist in screening autopsy cases for gross findings of plutonium in liver tissue. Indication of plutonium would alert the pathologist to a need for a more comprehensive tis,ue sampling pro gram. This work is in support of the National plutonium Registry

Promethium 147

D. McConnon and I. C. velson

Current efforts are oriented to ward a didgnostic method for inhaled promethium 147 oxide The earlier inhalation experiment utilizing human volunteers and promethium $143 \mathrm{ch} 10$ ride was abandoned on the advice of the BNW Human Testing Committee in favor of inhalation studies performed with the oxide. This aduce was based on the lact that the pressing need is for information on the oxide and, although a chioride experiment would be simpler to perform, the justifica tion for human testing was not so clear in the case of the chloride since it has a much smaller hazard potentul it an acceptable dose level the mass of promethium 143 oxide ls indequate to permit pro duction of the test aerosol. Samari um was the first cholce as a carrier for promethium It is not known if samarium behaves the same as promethium in a blological system Experi ments have been designed to determine this Initially samarium chloride and promethium chloride will be administered $\perp$ traienous $1 y$ to a group of rats with subsequent tissue analysis to determine if gross differences exist in the metabolism of samarium and promethium. If no gross differences exist, groups of rats will be exposed to $\mathrm{Sm}_{2} \mathrm{O}_{3},{ }^{147} \mathrm{Pm}_{2} \mathrm{O}_{3}$, and $\left({ }^{143} \mathrm{Pm}, \mathrm{Sm}\right)_{2} \mathrm{O}_{3}$ via inhalation to assess the appropriateness of the carrier in the rat. Again, if the results are favorable, similar tests will be conducted on beagle dogs, an animal large enough for whole body examination, to confirm the basis for human testins

An zerosol generator was designed, fabricated and tested Some special apparatus was necesari since the equipment is intended for use in human inhalation terting particle size studies here also performed to deter mine particle size distributions as a function of aerosol concentrations and other operating parameters. For the above mentioned samarium carrier and promethium acrosol, experiments wi1 be performed to ensure that the promethiun in distribited uniformiv throughout the samarium 


\section{PUBLICATIONS}

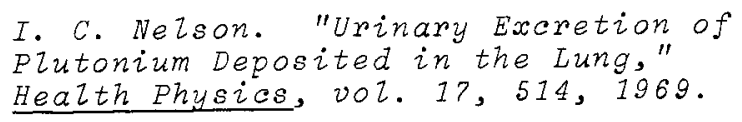

\section{PRESENTATIONS}

D. McConnon. "The Use of Electron Capture Decay Isotopes for Human Metabolism Studies," 14th Annual Health Physics Society Meeting, Pittsburgh, Pennsylvania. June 1969. 